\title{
Osäkerhetens återkomst. Att åldras i risksamhället
}

\author{
BENGT G ERIKSSON
}

I denna artikel speglas de äldres situation och samhällets ansvar mot bakgrund av en generell samhällsförändring i riktning mot vad som har kallats ett risksamhälle, präglat av osäkerhet och betoning på individuell ansvar. Den demografiska utvecklingen och välfärdssamhällets tilltagande svårigheter att leva upp till sina åtaganden diskuteras i relation till risksamhällets framväxt. Risksamhället innebär nya hot och svårigheter men öppnar också möjligheter för gruppen äldre att spela en större samhällelig roll.

\section{Industrisamhället och åldrandet - en seglivad tankefigur}

Åldrandet och de äldre kan betraktas ur en mängd olika perspektiv. Gemensamt är dock att åldrandet ses som en särskild och tydliggjord del av livet, ibland - och speciellt tidigare - karakteriserad som "den tredje åldern.» De senaste etthundra årens utveckling har inneburit att »den tredje åldern" på ett närmast dramatiskt sätt har förändrats till form och innehåll. I Sverige,

Bengt G Eriksson är docent i social omsorg och universitetslektor vid Karlstads universitet. som har bland den högsta medellivslängden för både kvinnor och män $(82,1$ respektive 77,5 år (Socialstyrelsen, 2001)) lever idag två generationer i åldrarna över pensionsåldern (Hollo, 2003). De äldres materiella förhållanden och hälsosituation har generellt sett förbättrats, i vårt land på ett högst påtagligt sätt ${ }^{1}$. Utbildningsnivån har blivit högre. Forskning om sociala nätverk tyder

1 Det finns dock indikationer på att denna trend kan vara på väg att brytas vad beträffar de äldres hälsa. Thorslund et al (2004) presenterar en undersökning som tyder på att hälsotillståndet i åldersgruppen 77-98 år i vissa avseenden har undergått en tydlig försämring under perioden 1992-2002. 
också på att de äldres sociala kontakter och sociala nätverk fungerar väl och bidrar till en god livskvalitet (Samuelsson, 2002).

Detta till trots lever i stora stycken fortfarande bilden av ålderdomen som en homogen och koherent livsperiod kvar. En period som i sin helhet präglas av avtagande livsfunktioner, förluster och kompensatoriska åtgärder från samhället. Ålderdomen betraktas som en "tom" period. Samhället bygger upp, eller sanktionerar, sjukvård och social omsorg men har i övrigt mycket lite att ge - och också små förväntningar på de äldre (Westlund, 2003). Det synsätt som fått epitetet eländesperspektivet (Tornstam, 1994, Andersson, 2002) fortsätter att dominera tankemönstret, även om många empiriska undersökningar dementerar eller i varje fall inte stödjer det.

Denna stereotypa syn på åldrandet kan dock numera i hög grad problematiseras och ifrågasättas. De allra flesta inom gruppen äldre motsvarar inte längre bilden av den osjälvständige och hjälpbehövande åldringen, prisgiven åt familjens, civilsamhällets, marknadens eller statens vilja och förmåga att möta ökande behov av hjälp och stöd. Istället lever de ett aktivt och självständigt liv, byggt på egna resurser, sitt sociala nätverk och det samhälleliga eller marknadsbaserade utbud ( $t$ ex i form av serviceinsatser och läkarvård) som betjänar befolkningen i sin helhet. Denna del av livet utgör för de flesta en ganska lång följd av år. Livets allra sista tid, karakteriserad av snabbt avtagande förmågor och sviktande hälsa, blir därför i många fall relativt kort och komprimerad. Att åstadkomma denna "compression of morbidity" (Gurner \& Thorslund, 2003) har också varit en utta- lad socialpolitisk strategi i många europeiska länder. ${ }^{2}$ Denna avslutande del av livet har också av gerontologer betraktas som så avskild från den längre delen av ålderdomen att den fått benämningen »den fjärde åldern« (a.a.). En vanlig indelning är att tala om yngre äldre - som regel i åldrarna från 65 till 75 år - samt äldre äldre, som är 75 år och däröver. Man kan nu notera att gränsen tenderar förskjutas upp mot 80 år.

\section{Demografin förändras och välfärden sätts ifråga}

De förändringar i befolkningens åldersmässiga sammansättning som pågått i Sverige och övriga Europa under en lång tid är väl kända. Andelen äldre - särskilt i de högsta åldrarna - ökar, medan gruppen unga och medelålders är mera konstant, eller ökar endast långsamt (Se SCB 2001, SCB 2003). Särskilt tydligt blir detta för Sveriges del under perioden efter år 2015.

2 "Compression of morbidity“ bygger på att sjukdomarna debuterar senare, samtidigt som den genomsnittliga livslängden är relativt konstant. Tidsperioden med sjukdom och allvarlig ohälsa minskar därför, liksom vårdbehovet. Eftersom nu även livslängden ökar talar man istället om "postponement of morbidity" - att sjukdomsperioden skjuts uppåt i åldrarna och att antalet friska år därför ökar, medan behovet av sjukvård är konstant. Ett mera pessimistiskt scenario uttrycks i begreppet "expansion of morbidity," innebärande att den genomsnittliga tiden av ett stort omsorgs- och vårdbehov ökar. Detta eftersom alltfler människor kan räddas från livshotande sjukdomar och skador, vilket förlänger tiden av hjälp- och vårdbehov (Gurner \& Thorslund, 2003). (Jfr. uttrycket "Den medicinska paradoxen« (a.a.) som uttrycker ungefär samma sak som "expansion of morbidity.") 
Även om de europeiska samhällena rent generellt kan karakteriseras som välfärdssamhällen har de utvecklats i skilda riktningar, beroende på historiska och kulturella faktorer. I den s $\mathrm{k}$ skandinaviska modellen ges välfärdspolitiken långt större uppgifter än i flertalet europeiska länder. Den ska bl a bidra till standardutjämning mellan olika grupper i samhället och för den enskilde under livsloppet. För att möjliggöra detta får staten en framträdande roll, medan arbetsmarknaden, civilsamhället och familjen tilldelas ett begränsat ansvar. Det förtjänar dock framhållas att alla europeiska välfärdssystem bygger på samverkan mellan stat, arbetsmarknad, marknad och civilsamhälle/familj.

Oavsett uppbyggnad och modell för fördelning av ansvar och arbetsuppgifter har många europeiska länder under senare år gjort inskränkningar i socialpolitikens verksamheter. Orsakerna har främst varit av ekonomisk natur, men andra faktorer spelar också in, $\mathrm{t}$ ex demografiska förändringar och möjligen också värderingsförskjutningar. Inte minst har åtstramningarna blivit tydliga i Sverige. Statliga, kommunala och landstingskommunala verksamheter har i många fall fått vidkännas neddragningar och besparingar.

Många av dessa förändringar gäller transfereringssystem och skatteuttag. Dessa faktorer spelar givetvis mycket stor roll också för gruppen äldre. Det pensionssystem som nu successivt implementeras kommer $t \mathrm{ex}$ för de allra flesta att innebära lägre pensioner än det gamla ATP-systemet. Om denna sida - transfereringssidan - är viktig för gruppen äldre, kan den andra sidan - tjänstesidan - många gånger vara ännu viktigare.
Försämringar i transfereringssystemen har också motiverats med att nivån på tjänstesidan därigenom skulle kunna upprätthållas. Hur ser det då ut när det gäller omsorg och vård för äldre? Gurner och Thorslund (2003) illustrerar hur antalet hemtjänstmottagare, personer i särskilt boende samt platser i somatisk akutvård relateras till antalet personer 80 år och äldre, under perioden 1960-2000.

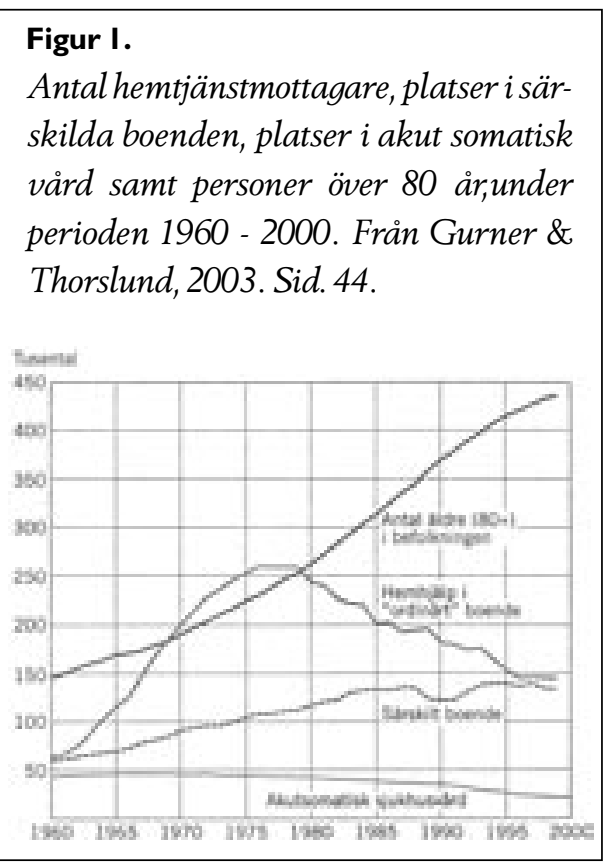

Diagrammet visar en dramatisk nedgång $i$ antalet hemtjänstmottagare, för perioden 1980 - 2000 med över 100000 personer. Antalet platser i särskilda boenden har ökat under hela perioden, medan de akutsomatiska vårdplatserna halverats. Alltmedan antalet personer 80 år och äldre tredubblats, från ca 150000 till 450000 under samma period. 
Välfärdens verksamheter har således förändrats eller minskat i omfattning. Det har ibland t o m uttryckts som att välfärdsstaten inte längre förmår leva upp till sina egna ambitioner - den har "abdikerat." Så drastiskt vill kanske inte alla uttrycka sig. Heikkilä, m fl (2002) konstaterar, efter en bred genomgång av välfärdssystemens utveckling i de skandinaviska länderna, att "The Nordic model stands stable but on shaky ground" (sid. 262). En annan tolkning skulle kunna vara att samhällets insatser följdriktigt minskas som ett resultat av de äldres förbättrade livssituation och därav minskade behov av omsorg och vård. De demografiska förändringarna har dock sannolikt ett större genomslag i motsatt riktning, d v s mot ett allt större omsorgs- och vårdbehov, totalt sett.

\section{Risksamhället}

Det är således uppenbart att den samhällsvision som målinriktat och styrt industrisamhället och moderniseringsprocessen inte längre fullt ut kan användas som beskrivningsmodell för det utvecklingsskede i vilket vi nu befinner oss. Det moderna samhällets trygga förankring $i$ tillväxt och ett ökande materiellt välstånd att fördela sviktar betänkligt i många europeiska länder. Så gör också dess socialpolitiska vision om ett samhälle som värnar om de svaga och sörjer för befolkningens välfärd, som ger vad Swedner (1996) kallat »en god färd genom livet."

En teori för beskrivning av samhället "efter" moderniseringen har utvecklats under den sammanfattande benämningen risksamhället (Beck, 1992). Det senmo- derna samhället karakteriseras av att nya former av hot och risker $\mathrm{i}$ allt större grad präglar samhället såväl som den enskilde individens liv. Det kan handla om industriella risker eller miljöhot, men också om risker som produceras i och genom de abstrakta, ofta världsomfattande system som alltmera påtagligt influerar också den enskildes vardagliga liv. Som exempel på sådana miljökatastrofer anförs ofta olyckan vid kärnkraftverket Tjernobyl i Ukraina, 1986. Dess konsekvenser drabbade människor även långt borta från olycksplatsen. Utsläpp av radioaktiva ämnen spreds av vindarna till andra delar av Europa, osynliga, omöjliga att förutse och därmed också omöjliga att skydda sig emot. Konsekvenserna visade sig i full omfattning först många år efter olyckan. ${ }^{3}$

Riskerna i dagens samhälle tenderar således att bli globala. Terrordåd av tidigare okänd omfattning kan drabba envar, i princip var som helst på jorden. Ett samhälles elförsörjning kan slås ut genom något abstrakt fel mycket långt borta. Okända krafters spekulation mot ett lands valuta kan få ödesdigra konsekvenser också för den enskildes ekonomi.

Termen risksamhälle kom att etableras med stor genomslagskraft genom Becks banbrytande verk Risk Society - Towards a New Modernity (1992) ${ }^{4}$. Beck har emel-

3 För mitt resonemang spelar andra yttringar av risksamhället än sådana som berör de ekologiska aspekterna en större roll. Inledningsvis berörs ändå dessa, eftersom de ofta återkommer i beskrivningar av risksamhället.

4 Originalets titel: Risikogesellschaft: Auf dem Weg in eine andere Moderne (1986). 
lertid själv senare ifrågasatt (Lidskog, et al, 1997) denna term. Frank Knight (1921, i Boyne, 2003) argumenterar för att man bör göra skillnad mellan begreppen risk (risk) och fara eller osäkerhet (uncertainty). Medan en risk kan uppskattas och beräknas, karakteriseras fara eller osäkerhet av sin "smygande," oförutsägbara karaktär. En fara kan inte uppskattas vare sig när det gäller sannolikheten för att den ska realiseras eller till de konsekvenser detta i så fall kommer att få. Begreppet risk skulle således snarare böra förknippas med det moderna samhället, med sin tilltro till (natur-)vetenskapliga metoder och instrument, med vars hjälp risker kan beräknas, kalkyleras och delvis också förebyggas. Beck väljer dock att behålla det invanda begreppet risk, medan Boyne (a.a.) föredrar att tala dels om risk, dels om "mätbar risk" (measurable risk).

Det traditionella industrisamhällets risker var i långt större utsträckning lokala, synliga och möjliga att åtgärda. Moderniseringens inriktning mot att minska och eliminera risker $\mathrm{i}$ arbetsliv, samhällsliv och privatliv, t ex genom arbetsmiljöåtgärder, trafiksäkerhetsarbete och en utbyggd socialpolitik, var ämnade att förverkliga visionen om "det goda samhället." I viss mening var industrisamhällets inriktning att "besegra naturen" ("the end of nature"), $\mathrm{t}$ ex genom att omvandla naturtillgångar till nyttiga produkter. Kampen stod mellan människan och naturen. Den osäkerhet som det innebar att vara utelämnad till en nyckfull natur skulle genom teknikens och vetenskapens framsteg gradvis övervinnas och elimineras. I ett sådant samhälle passade resonemanget om den trygga ålder- dom som skulle följa på ett ansträngande arbetsliv som hand i handske.

I våra tiders samhälle är det istället - $i$ viss utsträckning - mänsklighetens egna produkter, resultatet av utvecklingen, som utgör hot. Hoten är människoskapade, Beck och Giddens talar om "manufactured uncertainty" (Beck, 1998). Det är dessa "kulturprodukter - resultatet av själva den tekniska och ekonomiska utvecklingen som skapar risker och som gör samhället sårbart. Den osäkerhet som en nyckfull natur kunde utgöra har till stora delar kunnat övervinnas - människan har tämjt naturen - men återskapats i kulturens oförutsägbarhet. Beck (1994, cit. i Stoer, Rodrigues \& Magalhaes, 2003) talar om "the return of uncertainty to society" och menar att "more and more social conflicts are no longer treated as problems of order (which by definition are oriented towards clarity and decidability) but as problems of risk. Such risk problems are characterised by having no unambigous solutions (...) In the face of a growing lack of clarity (....) faith in the technical feasability of society disappears almost by necessity (sid. 8ff). Moderniseringens tilltro till vetenskapens möjligheter att lösa globala, nationella och individuella problem, att skapa det goda livet, har slagit tillbaka: Vetenskapen löser många problem men skapar också nya. Industrisamhällets optimism har ersatts av den reflexiva moderniseringen (Beck, 1992, Giddens, 1996, Lidskog et al., 1997).

\section{Det egna livet som projekt}

Med uttrycket social reflexivitet vill Giddens (2003) peka på det förhållandet att vi som individer ständigt måste skapa och 
återskapa vår sociala tillvaro. Medan kollektivt styrande traditioner och ritualer i det tidigare samhället ofta fungerade som riktningsgivare också för den enskildes olika ställningstaganden, måste dessa numera $\mathrm{i}$ långt högre utsträckning ske utifrån individen själv. Dessa val vägleds nu istället av reflexiv medvetenhet, överväganden och konsekvensbedömningar i ljuset av det egna livet. Vägledning hämtas inte från överindividuella för-sant-hållanden utan från den egna livshistorien. Att "förverkliga sitt livsprojekt» eller att "satsa på sig själv» har blivit etablerade slagord som i individualiseringens anda uttrycker social reflexivitet i termer av positiva möjligheter. Samtidigt är det uppenbart att åtskillnaden individer och grupper emellan tenderar att öka än mer, $t$ ex mellan sociala klasser eller grupper med olika utbildningsbakgrund. Den enskilde blir helt enkelt mera utelämnad, på gott och ont, till egna resurser i form av materiella tillgångar, socialt nätverk, kunskaper, social kompetens och självbild.

På samma sätt innebär utvecklingen mot ett risksamhälle att synen på välfärd och välfärdssamhället förändras. Beck (1998) menar, med hänvisning till Francois Ewald, att välfärdssträvandena i det moderna samhället främst syftade till att eliminera osäkerhet: „While the majority of social scientists have sought to explain the origins and construction of the welfare state in terms of class interests, the maintenance of social order or the enhancement of national productivity or military power, this argument understands the provision of services (health care), the creation of insurance schemes (pensions and unemployment insurance) and the regulation of the economy and the environment in terms of the regulation of security" (sid. 20). En heltäckande och allestädes närvarande välfärd utgjorde därför också ett mått på samhällets utvecklingsnivå och »kulturens» slutliga seger över "naturen.» Trygghet och säkerhet skulle genomsyra det moderna samhället, nära kopplat till en högteknologisk produktion, en effektiv ekonomi och en positiv syn på vetenskapens möjligheter. Som påpekats ovan menar Beck att det risksamhälle som nu utvecklas, den andra moderniseringen (Beck, 1986), innebär att frågan om samhällets möjligheter att skapa trygghet, säkerhet och att inge tillit helt har förändrats.

\section{Tillit i risksamhället}

Frågor om förtroende och tillit hänger således nära samman med den successiva övergången från ett industrisamhället till ett senmodernt samhälle, präglat av globala rörelser såväl tekniskt som ekonomiskt, politiskt och kulturellt. Tillit byggd på närhet i rummet, personlig kännedom och kulturell likhet ersätts av tillit till anonyma expertsystem, som den enskilde har en ringa kännedom om, men ändå tvingas lita till. Giddens (1996) talar här om wintimitetens omvandling« från tillit i första hand byggd på personlig kännedom - persontillit - mot tillit i relation till abstrakta system - systemtillit. Han använder termen urbäddning (disembedding) för att beskriva denna förändring av de sociala relationerna. Urbäddning innebär att relationerna lyfts ur sitt ontologiska sammanhang, blir abstrakta och opersonliga. Att leva i det senmoderna samhället innebär krav på acceptans och tillit utan att (alltid) kunna överblicka och förstå. 
Främst visar sig detta i relation till expertsystemen, de "system av tekniska utförare eller expertis som organiserar områden av den materiella och sociala omgivningen" (Lidskog et al, 1997, sid. 133). Den enskilde tvingas lita till expertisens kompetens just i dess funktion av expertis. Tilliten knyts till abstrakta system snarare än till enskilda och välbekanta personer. Tankarna går väl främst till abstrakta system som banktjänster, telekommunikation, elförsörjning eller bokningssystem för $\mathrm{t}$ ex tågbiljetter. Det är dock inte alltför långsökt att också exemplifiera med de expertsystem för vård och omsorg som byggs upp inom ramen för socialpolitiken. Omsorgs- och vårdpersonalen får som systemens representanter en central uppgift att återskapa tillit till dessa abstrakta system. Giddens (a.a.) talar här om reembedding, som innebär att de abstrakta expertsystemen återknyts till det lokala sammanhanget. Detta återknytande, som är av avgörande vikt för att en ny form av tillit, under senmodernitetens villkor, ska kunna uppstå, är av två slag (Giddens, a.a.): Dels handlar det om åtaganden med ansikte (facework commitments), dels om ansiktslösa åtaganden (faceless commitments). Ett ordinärt läkarbesök kan tjäna som exempel för båda formerna av kontakter; läkaren representerar ett facework commitment, en personlig kontakt men är samtidigt en representant för det oöverblickbara expertfält som sjukvården idag utgör för den enskilde. Den medicinbeställning som kan bli följden av läkarbesöket styrs av en administration, logistik och expedition som inte representeras av någon enskild person med vilken den hjälpsökande upprättar en relation (så som fallet i någon mening är med läkaren). Medi- cinhanteringen kan därför betraktas som ett faceless commitment.

\section{Att åldras i risksamhället}

På samma sätt som det moderna samhället i en mening erbjöd en trygg och koherent världsbild, genomfärgad av optimism och framtidstro, var också synen på åldrandet $\mathrm{i}$ detta samhälle präglad av ett slags lugn tillförsikt. Även om denna tid för den enskilde präglades av avtagande förmågor och tilltagande krämpor fanns det, mera långsiktigt och i samhällsperspektivet ändå anledning att se positivt på ålderdomen. Hälsotillståndet blev för varje generation bättre än för den föregående, de äldres ekonomiska standard förbättrades successivt. Och inte minst, det expanderande välfärdssamhället inriktades i stor utsträckning på de äldre och deras villkor. ${ }^{5}$ Att från pensioneringen och till livets slut befinna sig i rollen av potentiell eller reell konsument av välfärdstjänster och sociala trygghetssystem betraktades som mer eller mindre självskrivet.

Denna situation har genomgripande och på i historiskt perspektiv påfallande kort tid förändrats i väsentliga avseenden. Jag har pekat på tre grundläggande faktorer i denna samhällsomvandling. Den demografiska utvecklingen går mot en allt större proportion äldre i befolkningen. Detta i kombination med - så långt man nu kan överblicka en »permanent kris» när det gäller samhällets

5 En tyngdpunktsförskjutning från insatser riktade mot barn och unga mot insatser för äldre, har skett i EU-länderna, delvis som en konsekvens av förändrade demografiska förhållanden. Se t ex Stark och Regnér (2001), Thomson (1996, i Kautto, 2002). 
förmåga att fullgöra sina uppgifter inom välfärdens område. Denna välfärdsstatens partiella abdikering hänger i sin tur samman med den tredje faktor jag pekat på - den gradvisa successionen från ett samhälle genomsyrat av moderniseringens praktik och ideologi till ett samhälle präglat av risk och osäkerhet. Ett samhälle där lösningen blivit en del av problemet och där möjligheten att ta inteckningar i framtiden ersatts av krav på snabba insatser för att begränsa skador och främja social stabilitet. Osäkerhet har blivit en del av såväl samhällets som den enskildes liv.

Hur ter sig då åldrandet som livsfas och livet som äldre mot denna bakgrund? På vilket sätt och med vilka resultat samverkar dessa tre faktorer, sinsemellan och i relation till andra, mera flyktiga samhällsförändringar? Avslutningsvis vill jag skissera några tänkbara konsekvenser för åldrandet och de äldre.

Den demografiska förändringen innebär rent kvantitativt att en större andel av befolkningen befinner sig i livsfasen efter förvärvsarbetets slut. Gruppen aktiva, relativt friska människor inom denna andel ökar. Inom gruppen "efter förvärvslivet» finns också en andel med påtagliga brister i hälsa och livskvalitet. För de allra flesta gäller denna period den sista tiden i livet, karakteriserad av ett hälso- och allmäntillstånd som försämras relativt snabbt. Med stigande livslängd ökar också andelen personer som insjuknar i demenssjukdomar. Antalet personår ökar också inom denna grupp - ovan kallad den fjärde åldern - dock inte i lika stor omfattning som inom gruppen friska och aktiva äldre ${ }^{6}$. I varje fall gäller detta 2000-talets första decennier.

Det finns all anledning att se på gruppen aktiva, relativt friska äldre och gruppen äldre med stora och tilltagande livskvalitetsbrister som två åtskilda kategorier i diskussionen om de äldre. Den tanke om en samhällsomsorg som tar sin början relativt snart efter pensioneringen och som sedan förändras till sitt innehåll och ökar i omfattning efterhand som åren går, mister därmed av flera skäl sin aktualitet. Dels därför att den friska och aktiva äldres självbild och behov inte motsvarar omsorgstagarens eller patientens. Man identifierar sig inte med den som, efter väl förrättat värv (i yrkeslivet) nu ska "njuta sitt otium," parallellt med att ett beroendeförhållande till »den goda staten« eller välfärdens verksamheter i andra former gradvis utvecklas. Dels - och här kommer vi in på välfärdsstatens transition - för att samhället saknar möjlighet att följa med i en sådan utveckling. Det som byggdes upp som en välfärdsstat utgick från en helt annan typ av samhälle och en demografisk struktur som förändrats i genomgripande avseenden. Relationen mellan andelen barn/ungdomar, förvärvsarbetande respektive äldre skilde sig i dessa samhällen dramatiskt från dagens situation. Samhället var helt enkelt inte uppbyggt med tanke på en så liten andel förvärvsarbetande i relation till andelen barn/ungdomar/äldre ${ }^{7}$.

6 Jfr. dock det tidigare åberopade resonemanget från Gurner och Thorslund (2003), om begreppen "compression of morbidity, " "postponement of morbidity," samt »expansion of morbidity.»

7 Många andra faktorerän denna relation mellan försörjande och försörjda (age depency rate, Kautto, 2002) spelar givetvis in. Den stora produktivitetsökning, effektivisering och rationalisering som ländernas näringsliv och ekonomier genomgått är en sådan. Den innebär att levnadsstandarden kunnat öka för alla grupper i befolkningen. 
Då den allmänna folkpensionen infördes, 1913 , var endast $7 \%$ av befolkningen äldre än den pensionsålder som då beslutades, 67 år. Pensionsbeloppen var låga. Folkpensionen var ingen kostsam reform (Gurner \& Thorslund, 2003).

Framväxten av det senmoderna samhälle som ovan beskrivits som ett risksamhälle utgör således den tredje stora förändringen ${ }^{8}$.

\section{Kraven ökar på de äldre}

Det finns ändå anledning att se de äldre - och jag talar här om såväl de yngre äldre som de äldre äldre - som en speciellt utsatt grupp i detta sammanhang. Äldre människor är som regel i större utsträckning än medelålders och yngre beroende av de expertsystem som genomsyrar samhällets olika sektorer. Till detta kommer att de äldre är i behov av fler och mera frekventa tjänster från vissa av dessa sektorer - utan att för den skull nödvändigtvis kräva någon omfattande vård och omsorg. Det kan t ex vara fråga om återkommande rutinkontakter med vården för den som har åldersdiabetes. Det kan också handla om ekonomiska och juridiska frågor som aktualiseras efter makens bortgång.

Jag menar att de äldre på detta sätt kan

8 Framväxten av risksamhället innebär givetvis inte ett helt nytt samhälle, snarare är det fråga om en gradvis förändring. Denna förändring påverkar inte bara de äldre utan alla samhällsmedlemmar. Det kan därför vara rimligare - för det fortsatta resonemanget - att se risksamhället som en kontext eller bakgrund, inom vars ram de två andra förändringarna - de demografiska och de välfärdssamhälleliga - äger rum. betraktas som utsatta i dubbel bemärkelse i det senmoderna samhället. Dels genom "välfärdsstatens (partiella) abdikering," dels genom uppkomsten av nya former av risker (faror) och osäkerheter. På systemnivån handlar det om riskernas (farornas) karaktär, medan det på individnivån är en fråga om tillit.

I dagens samhälle krävs av de äldre en långt större förmåga att kunna "administrera sin tillvaro« mycket längre upp i åldrarna än tidigare. Detta kan betraktas som en form av den sociala reflexivitet varmed Giddens (2003) karakteriserar det senmoderna samhället. Så blir t e x möjligheterna till en god försörjning $i$ ålderdomen för allt fler en fråga om att ha investerat i en personlig pensionsförsäkring som ger god avkastning. Genom centralisering och professionalisering ökar avståndet - såväl psykologiskt som rumsligt - mellan den äldre och samhällets arrangemang för stöd och hjälp.

Tillit till abstrakta system (som $t$ ex sjukvård, försäkringssystem, hemtjänst) är således av avgörande betydelse i risksamhället. En tillit som, enligt Giddens (1996) måste återskapas i en process av återinbäddning (reembedding) av de sociala institutionerna. Men att systemen är abstrakta innebär ju just deras osynlighet (och ibland kanske också onåbarhet) för den enskilde. De abstrakta systemen blir synliga endast i och genom sina representanter och vid sina $\mathrm{s} \mathrm{k}$ tillgångspunkter (Giddens, a.a.). Tillit på individnivån, som tidigare kunde bygga på långvarig bekantskap, grannskap eller släktskap, måste återskapas i nuet, vid korta möten mellan systemrepresentanten och den äldre. Den förstnämndes upp- 
trädande blir därför av avgörande vikt för tilliten till systemet. Det handlar både om sådana situations- och personbundna kvaliteter som ett empatiskt förhållningssätt och en medveten etisk hållning, men också om trovärdighet när det gäller kunskaper och färdigheter.

\section{Omvärdering av de äldres erfarenheter och resurser}

Den demografiska och hälsomässiga utvecklingen innebär som nämnts att en allt större grupp i samhället utgörs av relativt friska, aktiva och yngre äldre, som ställer krav på och också själva kan bidra till full delaktighet i samhällslivet. I risksamhällets utveckling är denna grupp på flera sätt en tydlig resurs. Gruppen karakteriseras - och kommer att så göra ännu mer $\mathrm{i}$ framtiden - av sina resurser, snarare än av sina tillkortakommanden. De yngre äldre har, efter sitt arbetsliv, tid och energi att utveckla nya arenor. De har kunskaper och intresse för att ta aktiv del i samhällsfrågorna, inte minst i ett lokalsamhällesperspektiv. De har en omfattande erfarenhet, vunnen såväl i arbetsliv som i privatliv. De har på ett naturligt sätt lärt sig utnyttja modern informatonsteknologi - "the wired retired."Allt detta skapar en överblick och ett sinne för proportioner. Jag vill peka på två aspekter av denna samhällsresurs. ${ }^{9}$

9 Jag är givetvis medveten om den diskussion om synen på de äldre som ofta sammanfattas under termen ageism. Ageism innebär att åldrandet i sig uppfattas som något negativt och att de äldre drabbas av nedsättande omdömen, fördomar och diskriminering (Jönsson, 2002). I det resonemang jag för ligger det nära till hands
En konsekvens av risksamhället är insikten att experterna inte längre kan ge alla svar. Den trygga tilliten till expertis och vetenskap har ersatts av ett individualiserat sökande, där den enes för-sant-hållanden kan vara lika mycket värda som den andres. "Society has become a laboratory where there is absolutely nobody in charge» (Beck, 1998, sid. 9). Inte heller politikens företrädare förmår ge de lugnande beskeden: " This is why we do not trust politicians and experts: because they are ignoring the dynamic, keeping up the facade, because they do not know how to say they don't know" (Franklin, 1998, sid. 5). I en situation där den "upplysta allmänheten" kan ge svar i lika hög grad som experter och politiker får själva samtalet en central roll. I detta samhälleliga samtal, byggt på entill-en-relationer av hög kvalitet och varaktighet, kan de yngre äldre (till en del också de allra äldsta) spela en stor och viktig roll. En sådan utveckling ligger också helt i linje med grundtankarna inom den teori om gerotranscendens som utvecklats bl a av Tornstam (1973, 1992, 1993, 1994, 1996, Cumming, 1960, Solem, 1995). Att utvecklas mot gerotranscendens innebär att individens inriktning på sig själv, sin tillvaro och sina villkor (ego-centrism), ersätts av ett tilltagande intresse för andra människor, andra rum och andra tider. Den enskilde ser sig i högre grad som en del i ett större histo-

att betrakta ageismen som ett uttryck för det moderna industrisamhällets värderingar. I detta samhälle, där experterna är de givna vägledarna in i framtiden, värderas snabba högteknologiska förändringar och expertis högst. Ideal som naturligt kommer att ifrågasättas alltmer i det framväxande risksamhället. 
riskt och rumsligt sammanhang. Gränserna - mellan personen ifråga och andra, mellan nutid, dåtid och framtid, mellan människa och natur, tunnas ut och blir mindre viktiga.

\section{Autentiska vänskapsrelationer - byggda på fria val}

Den andra aspekt jag vill ta upp handlar också om relationer. Pahl (1998), pekar på den möjlighet som ligger $\mathrm{i}$ att utveckla autentiska vänskapsrelationer, i ett samhälle präglat av tilltagande klyftor mellan olika grupper. Inom olika områden i samhället pågår en flykt från av traditionalismen formade, fixerade sociala roller, det må vara som anställd, släkting, hemmafru eller något annat. Istället söker den enskilde i individualiseringens tidevarv forma sitt eget liv och skapa relationer till andra människor, på basis av autentiska, från konventionen fria önskemål. "The privatization of the career may turn out to be the most radical privatization of them all« (Pahl, 1998, sid. 102). I denna värld »bortom traditionen" (Beck, 1998) kommer vänskapsförhållanden att spela en allt större roll. Pahl (a.a.) följer Aristoteles tankegångar om tre olika slag av vänskap »based respectively on utility, on pleasure and on character» (sid. 104). Den tredje formen av vänskap bygger på jämlikhet, öppen kommunikation och autentiska relationer. En vänskap fri från konkurrens och nyttighetstänkande. Utvecklingen mot ett risksamhälle, med dess förlust av tilltro till traditioner och auktoriteter, ökar behovet av detta slags relationer. Men den skapar också möjlighet för sådana relationer att utvecklas - på basis av enskildas fria val. De skulle kunna fungera som "the social glue» (Pahl, a.a.) i framtidens samhälle. Här kan de äldre som grupp, i kraft av sina resurser, spela en stor och viktig roll. Så sker redan idag, t ex i frekventa och nära kontakter mellan generationerna. Med samhällets utveckling mot kontakter byggda utifrån fria val på tvärs av t ex släktskap och konvention, kan äldre människor få en allt viktigare roll. Så kan äldre, en grupp som under modernismen hamnat allt mer på undantag, åter komma att spela en viktig roll. Nu inte i kraft av sitt ägande eller sitt kunskapsmonopol, som under den för-moderna tiden, utan genom att vara en människa i relation till andra människor.

\section{Fokuserad och flexibel omsorg med vardagslivet i fokus}

Jag har hittills i huvudsak berört konsekvenser av risksamhället i relation till den grupp äldre som karakteriserats som yngre äldre. Många personer över 75 år och således karakteriserade som äldre äldre har - och kommer i allt större omfattning att besitta - resurser av det slag jag ovan tillskrivit de yngre äldre. Gentemot de äldre äldre som grupp ställs dock större krav på samhällelig beredvillighet och närvaro. Denna grupp är i större behov av omsorg och vård.

Därför behövs en flexibel samhällelig organisation som kan anpassas till snabbt föränderliga behov. Flexibilitet kräver samarbete, samordning och små organisatoriska enheter. Något som i sin tur förutsätter ett utvecklat ledarskap. „Det måste så att säga finnas en ansvarig utgivare för omhändertagandet av varje äldre människa» (Jersild, 2003). De yrkesgrupper som möts och sam- 
arbetar i äldreomsorgen måste göra det utifrån ömsesidig respekt för den andres professionalitet och specifika kunskap.

En sådan omsorg och vård kräver professionella utövare. Behov av sjukvård måste kunna mötas med den bästa tänkbara teknologi och en effektiv vårdorganisation. Samtidigt som det måste vara en ambition att begränsa insatserna, att undvika medikalisering och "patientgörande» så långt som möjligt. Den omvårdnad som omgärdar de medicinska insatserna måste vägledas av humanism och en genomtänkt etisk grundsyn. Den sociala omsorgens utmaning är omfattande - här handlar det om att bygga professionaliteten på ett bevarat vardagsliv, bibehållen autonomi och personlig integritet för den enskilde. En professionalisering på livsvärldens villkor.

Vidare krävs utrymme för nära och personliga relationer till systemens representanter. Kanske mest tydligt i omsorg och vård för människor i livets slutskede. Men också för boende inom äldreomsorgens institutioner, liksom för hemmaboende med stora omsorgs- och vårdbehov, krävs en verksamhet som präglas av närhet, tillit, förutsägbarhet och personliga relationer. Här tydliggörs för övrigt frågor om tillit än mer, eftersom de ojämna styrkeförhållandena parterna emellan är så mycket tydligare. Kort sagt, vad som krävs är en social omsorg och vård för "den fjärde åldern." Odén (2004) poängterar vikten av detta perspektiv och varnar för ensidig fokusering på de yngre äldre, i debatten om framtidens äldreomsorg. "Vem tar ansvar för trygghet och utveckling av de växande skarorna människor som blir 80 år och äldre? De som inte har mycket att vinna på ett 'flexibelt livslopp'. De som inte längre orkar planera för sin egen framtid och som försjunker i sitt nu i väntan på döden. Även de har rätt till 'människans värde och människans väl'»(sid. 33).Slutligen: Framväxten av risksamhället kan givetvis, ur ett traditionalistiskt perspektiv betraktas som ett hot, där mödosamma politiska och vetenskapliga ansträngningar att skapa trygghet och ordning kastas över ända, medan det oväntade och okontrollerbara träder i dess ställe. Franklin (1998) pekar på att utvecklingen också innebär möjligheter och efterfrågar ett nytt språk för att beskriva förändringen, ett språk som tar "the reality of everyday life as its starting point.... This language is not yet formulated, but it has to be a language that resonates with our experience and can take us forward into the unknown, opening up the possibility of living creatively with risk and uncertainty. It offers an alternate strategy to the politics of nostalgic community" (sid. 2).

Anm: Artikeln bygger på en text som i omarbetad version kommer att ingå som avslutningskapitel i Eriksson, B. \& Wolf, J. (2004) European Perspectives on Elderly People. Frankfurt am Main: Peter Lang Verlag. Ingår i serien European Social Inclusion/Sozialgemeinschaft Europa. Redaktörer Wolf Bloemers och Fritz-Helmut Wisch. Under utgivning. 


\section{Referenser}

Andersson, L. (red.) (2002) Socialgerontologi. Lund: Studentlitteratur.

Beck, U. (1986) Risikogesellschaft: Auf dem Weg in eine andere Moderne. Frankfurt am Main: Suhrkamp Verlag.

Beck, U. (1992) Risk Society. Towards a New Modernity. London: Sage.

Beck, U. (1998) Politics of Risk Society. I J. Franklin (Red.) The Politics of Risk Society. Oxford: Polity Press.

Boyne, R. (2003) Risk. Buckingham: Open University Press.

Cumming, E. et al (1960) Disengagement - A tentative Theory of Aging. Sociometry 23:23-35.

Franklin, J. (1998) Introduktion. I J. Franklin (Red.) The Politics of Risk Society. Oxford: Polity Press.

Giddens, A. (1996) Modernitetens följder. Lund: Studentlitteratur.

Giddens, A. (2003) Sociologi. Lund: Studentlitteratur.

Gurner, U. \& Thorslund, M. (2003) Dirigent saknas i vård och omsorg för äldre. Stockholm: Natur och Kultur.

Heikkilä, M., Hvinden, B., Kautto, M., Marklund, S. \& Ploug, N. (2002) Conclusion. The Nordic model stands stable but on shaky ground. I M. Kautto, M. Heikkilä, B. Hvinden, S. Marklund \& N. Ploug. Nordic Social Policy. Changing Welfare States. London och New York: Routledge.

Hollo, A. (2003) Seniorhälsa - ett svenskt pilotprojekt. Projektrapport. Stockholm: Landstingsförbundet och Svenska Kommunförbundet.

Jersild, P. C. (2003) Förord. I U. Gurner \& M. Thorslund, Dirigent saknas i vård och omsorg för äldre. Stockholm: Natur och Kultur.

Jönsson, H. (2002) Ålderdom som samhällsproblem. Lund: Studentlitteratur.

Kautto, M. (2002) Changes in age structure, family stability and dependency. I M. Kautto, M. Heikkilä, B. Hvinden, S. Marklund \& N. Ploug. Nordic Social Policy. Changing Welfare States. London och New York: Routledge.

Lidskog, R., Sandstedt, E. \& Sundqvist, G. (1997)
Samhälle, risk och miljö. Lund: Studentlitteratur.

Odén, B. (2004) Fjärde åldern döljs när ålderstrappan rivs. Äldre $i$ Centrum, nr 1/2004.

Pahl, R. (1998) Friendship: the Social Glue of Contemporary Society? I J. Franklin (Red.) The Politics of Risk Society. Oxford: Polity Press.

Samuelsson, G. (2002) Det sociala åldrandet. I O. Dehlin, B. Hagberg, Å. Rundgren, G. Samuelsson \& B. Sjöbeck: Gerontologi. Åldrandet i ett biologiskt, psykologiskt och socialt perspektiv. Stockholm: Natur och Kultur.

SCB (2001) Befolkningsprognos för åren 2001 - 2050. Statistiska Centralbyrån.

SCB (2003) Folkmängd i tusental 2002 samt prognos 2003 - 2050. Samtliga. www.scb.se/statistik/be0401_tab3.asp

Socialstyrelsen (2001) Folkhälsorapport 2001.

Solem, P. E. (1995) Aktivitet eller gerotranscendens? Et kritisk lys på sosialgerontologisk teori. IS. O. Daatland \& P. E. Solem Aldersforskning i kritisk lys. Oslo: Norsk Gerontologisk Institutt, rapport nr 2/1995.

Stark, A. \& Regnér, Å. (2001) I vems händer? Om arbete, genus, åldrande och omsorg i tre EUländer. Linköping: Linköpings universitet, Tema Genus, Rapport nr 1:2001.

Stoer, S. A., Rodrigues, D. \& Magalhaes, A. M. (2003) Theories of Social Exclusion. Frankfurt am Main: Peter Lang Verlag.

Swedner, H. (1996) Socialt förändringsarbete. En tankeram. Stockholm: Liber.

Thorslund, M., Lennartsson, C., Parker, M. G. \& Lundberg, O. (2004) De allra äldstas hälsa har blivit sämre. Läkartidningen, 17/2004, vol .101, 1494-1499.

Tornstam, L. (1973) Att åldras: Socialgerontologiska perspektiv. Uppsala: Akademisk avhandling.

Tornstam, L. (1992) Gerotranscendence - empirical evidence of a new theoretical concept. Submitted manuscript.

Tornstam, L. (1993) Livsformer, åldrande och välbefinnande: En samnordisk studie. I K. Wer- 
ness, J-E. Ruth \& L. Tornstam. Livslöp blant gamle i Norden. Rapport 2-1993. Oslo: Norsk gerontologisk institutt.

Tornstam, L. (1994) Åldrandets socialpsykologi. Stockholm: Rabén Prisma.

Tornstam, L. (1996) Caring for the Elderly. Intro- ducing the Theory of Gerotranscendence as a Supplementary Frame of Reference for Caring for the Elderly. Scandinavian Journal of Caring Sciences, 1996; 10: 144-150.

Westlund, P. (2003) Gammal, sjuk och handikappad. Äldreomsorg 3/2003.

\section{Summary}

\section{The return of uncertainty. Ageing in the risk society}

This article is built upon three foundational issues: demographic development, changes within the welfare state, and the understanding that society is changing towards what has come to be known as the risk society. These three changes are tied together in a discussion about possible implications for the elderly and for ageing.

Demographic changes suggest in part that the number of elderly is on the rise, and that in the long term the number of older elderly in particular is increasing, especially when one takes note of the ratio of working members of the population to non-working members of the population (the age dependency rate). The changes within the welfare state - changes which tend to follow the same pattern in all Western European countries to a great extent - are characterized by a gradual reduction in the scope and numbers of services and undertakings. The concept of the risk society describes societal development after the modernization of the industrialized society. Modernization is characterized by a desire to reduce or eliminate risks and threats, to tame nature, and to create a secure society built upon a gradual development of science, economics, and social welfare. The risk society presently developing is, to a certain extent, characterized by new, largely man-made risks and dangers. Environmental catastrophes, the collapse of information systems, and global terrorism are examples of such new threats. Abstract and large-scale systems that impact the individual are also sensitive to change and influence to a great extent. What is intended as a solution can often become part of the problem.

The individual must refer to him/herself and to his/her own resources to a great extent. Societal development also increases the demand on the elderly who must to a greater degree administrate their own existence, even in advancing years. This development creates possibilities for the elderly to play a more active societal role. Empowered by their knowledge, experience, and the time at their disposal, the elderly can participate in society's marketplace of ideas and discussions, and participate in relationships based upon free choice, separate from conventional and familial relationships. For the older elderly, with a greater need for care and medical treatment, a flexible, clearly defined and competent societal system of assistance is needed. 